\title{
Structural and functional characterization of the 5' upstream region of a glutamine synthetase gene from Scots pine
}

\author{
Concepción Avila a , Francisco R. Cantón ${ }^{\mathrm{a}}$, Pilar Barnestein ${ }^{\mathrm{a}}$, \\ María-Fernanda Suárez ${ }^{a}$, Pierre Marraccinia ${ }^{{ }^{* *}}$, Manuel Rey ${ }^{\mathrm{b}}$, Jaime M. Humara ${ }^{\mathrm{c}}$, \\ Ricardo Ordás ${ }^{\mathfrak{c}}$ and Francisco M. Cánovas ${ }^{{ }^{*}}$ \\ ${ }^{a}$ Departamento de Biología Molecular y Bioquímica, Instituto Andaluz de Biotecnología, Unidad Asociada UMA-CSIC Facultad de Ciencias, \\ Universidad de Málaga, 29071 Málaga, Spain \\ ${ }^{\mathrm{b}}$ Laboratorio Fisiología y Biotecnología Vegetal, Facultad de Ciencias, Universidad de Vigo, 36200 Vigo, Spain \\ ${ }^{\mathrm{c}}$ Laboratorio Fisiología Vegetal, Departamento BOS, Universidad de Oviedo, 33071 Oviedo, Spain
}

(Received 5 July 2001; accepted 25 January 2002)

\begin{abstract}
We report here the isolation and characterization of a genomic clone encoding Scots pine ( $P$. sylvestris) cytosolic glutamine synthetase GS1a. The clone contains the 5' half of the gene including part of the coding region organized in seven exons, interrupted by 6 introns and 980 bp upstream of the translation initiation codon. Earlier experiments carried out in our lab have shown that the GS1a gene is expressed in a light dependent fashion during the initial stages of Scots pine development. These data suggest a specific role for GSIa in ammonia assimilation in photosynthetic tissues of pine seedlings similar to the physiological role of GS2 in angiosperms. We have used a transcriptional fusion to uidA to transform pine cotyledons and Arabidopsis and demonstrated the ability of this 5'-upstream sequence to drive gene expression in both species and light regulation in Arabidopsis.
\end{abstract}

cytosolic glutamine synthetase / conifer / gene expression / $\mathbf{N}$ metabolism

Résumé - Caractérisation structurale et fonctionnelle de la région 5' du gène de la glutamine synthetase du pin sylvestre. Un clone génomique codant la glutamine synthetase cytosolique GSla de pin sylvestre ( $P$. sylvestris) a été isolé et caractérisé. Ce clone contient la moitié 5 ' du gène comprenant une partie de la séquence codante organisée en 7 exons séparés par 6 introns et également une séquence de 980 pb en amont du codon d'initiation de la traduction. Des expériences préliminaires menées dans notre laboratoire ont montré que la lumière régule l'expression du gène GS1a pendant les étapes initiales du développement du pin sylvestre. Ces données suggèrent un rôle spécifique de GS1 a dans l'assimilation des ions ammonium par les tissus photosynthétiques des plantules de pin analogue au rôle physiologique de GS2 chez les angiospermes. Nous avons préparé une fusion transcriptionnelle avec le gène uidA pour transformer des cotylédons de pins ainsi qu'Arabidopsis. Nous avons ainsi démontré la capacité de cette séquence 5' de 980 pb à diriger (1) l'expression du gène chez ces deux espèces et (2) sa régulation par la lumière chez Arabidopsis.

glutamine synthetase cytosolique / conifère / expression génique / métabolisme de l'azote

\section{INTRODUCTION}

Glutamine synthetase (GS) plays a central role in nitrogen metabolism of higher plants. GS is responsible for the primary assimilation of ammonia produced by nitrate reduction or fixation of dinitrogen as well as the reassimilation of ammonia released by photorespiration and other metabolic processes. The various roles of GS in plant metabolism are undertaken by different isoforms encoded by a small multigene family [10]. As occurs in angiosperms it seems that a small multigene family could be operative in gymnosperms [12]. In the last years our studies have focused on

\footnotetext{
* Correspondence and reprints

Tel.: 3452131942; fax: 3452132000; e-mail: canovas@uma.es

** Current address: Nestlé Research Center Tours, Plant Science and Technology, 101 Gustave Eiffel, BP 9716, 37097 Tours Cedex 2, France
} 
ammonia assimilation in pine and studying regulation of the genes involved in the process [7]. Two distinct but homologous nuclear genes for GS have been detected and colocalized in the pine genome [2] both of them encoding cytosolic isoforms in conifers, GSIa and GS1b [1], but differentially expressed in pine seedlings [3].

Molecular data derived from the characterization of a GSI $a$ cDNA clone showed that the gene is actively expressed in chloroplast containing tissues of developing seedlings and the level of the transcript was affected by developmental and light conditions [9]. Here, we present the DNA sequence of a partial genomic clone containing 7 exons of the coding region of GSla gene. The clone includes 980 bp upstream of the functional ATG. So far, very few studies involving genomic clones from gymnosperms have been reported in the literature $[4,16,18]$, and none of them correspond to nitrogen metabolism. We have studied the promoter activity of the 5 '-untranslated region using fusions with the reporter gene uidA and the presence of DNA-protein interactions in the 5'flanking region of GS1a gene from Scots pine.

\section{MATERIALS AND METHODS}

\subsection{Isolation of a genomic clone containing GS1 sequences in pine}

Scots pine genomic DNA was digested with EcoRI and size fractionated by electrophoresis. Fragments were ligated to $\lambda$ gt 10 and recombinant clones containing the GSIa gene were identified by screening using the 5'end of the cDNA clone previously isolated [8].

The fragment released from one of these clones by enzyme digestion was subcloned into the plasmid pGEM-3Z to generate the clone pGS217 and used for analysis and sequencing.

\subsection{Fusions of the 5'region of GS1a to the GUS reporter gene}

The 981 bp sequence upstream of the translation codon was isolated from the clone by Hae III digestion. The resulting fragment was subcloned into the vector pBI101 [15] creating a GS1: uidA gene fusion. The GS1 T-DNA construct, and also two controls, which were the original plasmid pBI121 containing the CaMV 35S promoter and pBI101, a plasmid containing a promoter-less $1.87 \mathrm{~Kb}$ GUS cassette in the binary vector $\mathrm{pBin} 19$, were transformed individually in Agrobacterium tumefaciens LBA4104.

\subsection{Transient and stable transformation with the gene constructs}

A Biolistic PDS-1000/He apparatus from Bio-Rad was used for particle bombardment of $P$. pinea cotyledons excised from embryos germinated for one day. After bombardment, cotyledons were maintained in the same medium where they were bombarded until GUS assays were performed $24 \mathrm{~h}$ after as described before [19].

For stable transformation, Arabidopsis thaliana WS ecotype plants were grown at $24{ }^{\circ} \mathrm{C}$ under a $16 \mathrm{~h}$ light $/ 8 \mathrm{~h}$ dark regime and vacuum infiltrated as is described elsewhere [5]. T1 seeds were harvested in bulk and transformed seeds were selected in MS plates containing $50 \mu \mathrm{g} \mathrm{mL}^{-1}$ kanamycin. T2 seeds were harvested individually and kept for further analysis.

Histochemical GUS assays in bombarded cotyledons were performed as described by Rey et al. [19] whereas the fluorometric assay of gus in extracts of transgenic Arabidopsis were performed as described by Jefferson [14]. A 35S-promoter derivative pBI121 and promoter-less pBI101 plasmids were used as controls.

\subsection{Gel retardation analysis}

A DNA fragment used for gel retardation analysis containing a sequence from the 5' -untranslated region of GS1a was obtained by cleavage with restriction enzymes of the genomic clone pGS217. The fragment containing the $\mathrm{A} / \mathrm{T}$ - rich region of $173 \mathrm{bp}$ long was electrophoresed in 5\% acrylamide gels excised and eluted by diffusion into $0.5 \mathrm{M} \mathrm{NH}_{4} \mathrm{OAc}$. Binding was carried out in $15 \mu \mathrm{l}$ of $10 \mathrm{mM}$ Tris (pH 8), 1 mM EDTA, $100 \mathrm{mM} \mathrm{NaCl}, 2$ mM DTT, 10\% glycerol and $2 \mu \mathrm{g}$ of denatured salmon sperm DNA (binding buffer). The DNA (1-2 ng) labeled by filling in reaction with Klenow was incubated with $4 \mu \mathrm{g}$ of crude nuclear extract as a source of protein as described previously [11]. Mixes were incubated for $30 \mathrm{~min}$ on ice. In non specific competition experiments 0 to $0.5 \mu \mathrm{g}$ of poly $\mathrm{dI}-\mathrm{dC}$ was also included in the mixes. At the end of the incubation period 1/10th of the mix volume of loading buffer was added and samples were loaded on a $5 \%$ polyacrylamide $2 \%$ glycerol pre-electrophoresed gel. Running buffer was $0.5 \times$ TBE. Gels were run in the cold room at $10 \mathrm{~V} \mathrm{~cm}^{-1}$ for $2-5 \mathrm{~h}$.

\section{RESULTS AND DISCUSSION}

\subsection{Sequencing and structural characteristics of the pine GS1 genomic clone}

A $\lambda$ gt10 subgenomic library of Scots pine was screened for GS clones using the previously isolated pGSP114 pine GS cDNA [8]. About $1 \times 10^{6}$ recombinant clones were screened and four positives were isolated. One of these, pGS217 was subcloned and further characterized. As an initial step the genomic clone was entirely sequenced and determined to be $2543 \mathrm{bp}$ in length. The comparison of nucleotide sequences between the gene and the cDNA [8] showed that the fragment contained the 5' half of the gene including part of the coding region organized in seven exons, interrupted by 6 introns and 980 bp upstream the translation initiation codon (figure 1).

The sizes of introns in the GS1 genomic clone were between $91 \mathrm{bp}$ and $282 \mathrm{bp}$ as shown in table $I$, all of them having the usual range size for angiosperm introns, which are typically shorter than most mammalian introns [23]. The AT percentage in higher plants introns is usually between $70 \%$ described for dicot plants and around $60 \%$ for monocot plants [22]. Unfortunately not many data are available for gymnosperm genes, however the introns in the GS1 clone showed an average AT percentage around $64 \%$, which is within the range reported for angiosperms. We have also analyzed the sequences of 5 'and 3 'splice sites in all 6 pine cytosolic GS 


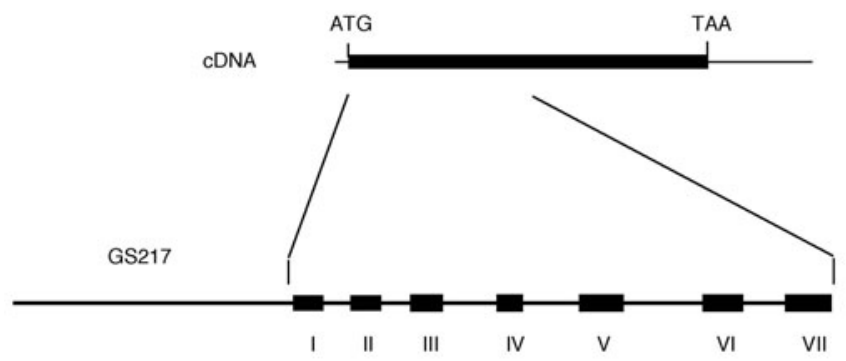

$-100 \mathrm{bp}$

Figure 1. Comparative diagram of the pGS217 genomic clone and the full-length cDNA corresponding to the GS1a clone. Closed boxes represent coding regions. Exons are denoted by roman numbers from I to VII. Untranslated regions including introns are represented by a bar. The nucleotide sequence data reported will appear in the EMBL data bank under the accession number AJ 225121.

Table I. Characteristics of introns in the pGS217 pine genomic clone.

\begin{tabular}{lccc}
\hline Intron n $^{\mathbf{0}}$ & Size (bp) & $(\%) \mathrm{A} / \mathrm{T}$ & $(\%)$ Pyrimidines \\
\hline $\mathbf{1}$ & 107 & 62.6 & 40 \\
$\mathbf{2}$ & 91 & 63.7 & 65 \\
$\mathbf{3}$ & 282 & 69.8 & 50 \\
$\mathbf{4}$ & 96 & 63.5 & 40 \\
$\mathbf{5}$ & 236 & 60.4 & 70 \\
$\mathbf{6}$ & 151 & 63.6 & 60 \\
\hline
\end{tabular}

introns and compared them with monocot and dicot plants, yeast consensus and vertebrate splice consensus sequences. The strict requirement in both sides of the intron for: G/GT in the 5'site and $\mathrm{AG} / \mathrm{G}$ in the 3 'end indicates a general use in all compared organisms.

We have also analyzed the presence of putative elements in the 5 ' region of the gene. There is a canonical TATA box at -35 bp from the transcription start site and a putative CAAT box at -138 bp. The 5 ' region also contains two A/T-rich sequences starting at -720 and -540 and 173 and 190 bp long respectively.

\subsection{GUS expression in pine cotyledons and transgenic Arabidopsis}

A transcriptional construct $(\mathrm{C} 1)$ containing the complete 980 bp upstream the translation initiation codon fused to the GUS gene was created. The chimeric gene was used to test transient expression in $P$. pinea cotyledons. According to GUS histochemical assays, the 5'upstream region of the pine gene was able to drive gene expression in pine cotyledons. To further characterize the function of the 5'upstream region of the pine GSIa gene, stable GUS expression was studied in transformed Arabidopsis plants. Expression of the reporter
Table II. Effect of ammonium, light and dark treatments on GUS expression in transgenic Arabidopsis grown at $24^{\circ} \mathrm{C}$ under a $16 \mathrm{~h}$ light $/ 8 \mathrm{~h}$ dark regime. Plants at the rosette stage were used. GUS activity was undetectable in roots and only data from the shoot apex are showed. Activities of $\mathrm{C} 1$ plants from 7 independent transformed lines were determined individually. The average $+/-$ SD data of at least 3 different experiments are shown. Plants grown in a 16-h light/8-h dark regime were transferred to a medium containing $10 \mathrm{mM} \mathrm{NH}_{4} \mathrm{Cl}$ $(\mathrm{C} 1 / \mathrm{N})$, continous light $(\mathrm{C} 1 /$ light $)$ or continuous dark $(\mathrm{C} 1 /$ dark $)$ for 3 days. A promoter-less derivative pBI101 was used as control.

\begin{tabular}{ll}
\hline Sample & MU $\left(\mathbf{p m o l ~} \mathbf{~ g}^{-1}\right.$ protein $\left.\mathbf{~ m i n}^{-1}\right)$ \\
\hline Control (-) & 1.47 \\
C1 & $31.6+/-1.05$ \\
C1/N & $24.6+/-3.16$ \\
C1/light & $60.9+/-2.57$ \\
C1/dark & $3.05+/-0.75$ \\
\hline
\end{tabular}

gene was absent or very low at the seedling and rosette stages, but apparent in adult plants with floral stems. These data therefore show that the 5'upstream region of pine GSla gene is able to drive gene expression in an heterologous system. Moreover, our results are consistent with the report of Kojima et al. [17] indicating that a pine gene promoter can be operative in angiosperms and therefore suggesting that transcriptional machinery is well conserved between angiosperms and gymnosperms.

GSIa abundance determined in pine seedlings was unchanged when they were supplied with either inorganic nitrogen, nitrate or ammonium [6], however illumination increased the amount of the GS1 transcript [9]. In order to determine whether or not the expression driven by the $980 \mathrm{bp}$ sequence from the GSla gene is affected by these external stimuli in an heterologous system, GUS activity was measured in seven $\mathrm{C} 1$ independent transgenic lines following either supply with ammonium or light/dark treatments. As shown in table II, no meaningful changes were observed in $\mathrm{NH}_{4}{ }^{+}$-treated plants with regard to controls. By contrast, GUS activity levels were highly influenced by light in close agreement with light-enhanced GS transcript abundance in pine cotyledons.

\subsection{Analysis of DNA-protein interactions in the 5' region of GSIa gene from Scots pine}

We have carried out an in vitro study of interactions between nuclear factors from Scots pine cotyledons and an $\mathrm{A} / \mathrm{T}$-rich sequence in the upstream region of GSIa gene using the technique of gel retardation analysis. The fragment was end labeled with ${ }^{32} \mathrm{P}$ and incubated with crude nuclear extracts from Scots pine cotyledons. The concentration of salmon sperm DNA and poly dI-dC needed to eliminate non specific binding was first established $(2 \mu \mathrm{g}$ and $0.5 \mu \mathrm{g}$ per assay, respectively). The binding reactions were electrophoresed on acrylamide gels to resolve 


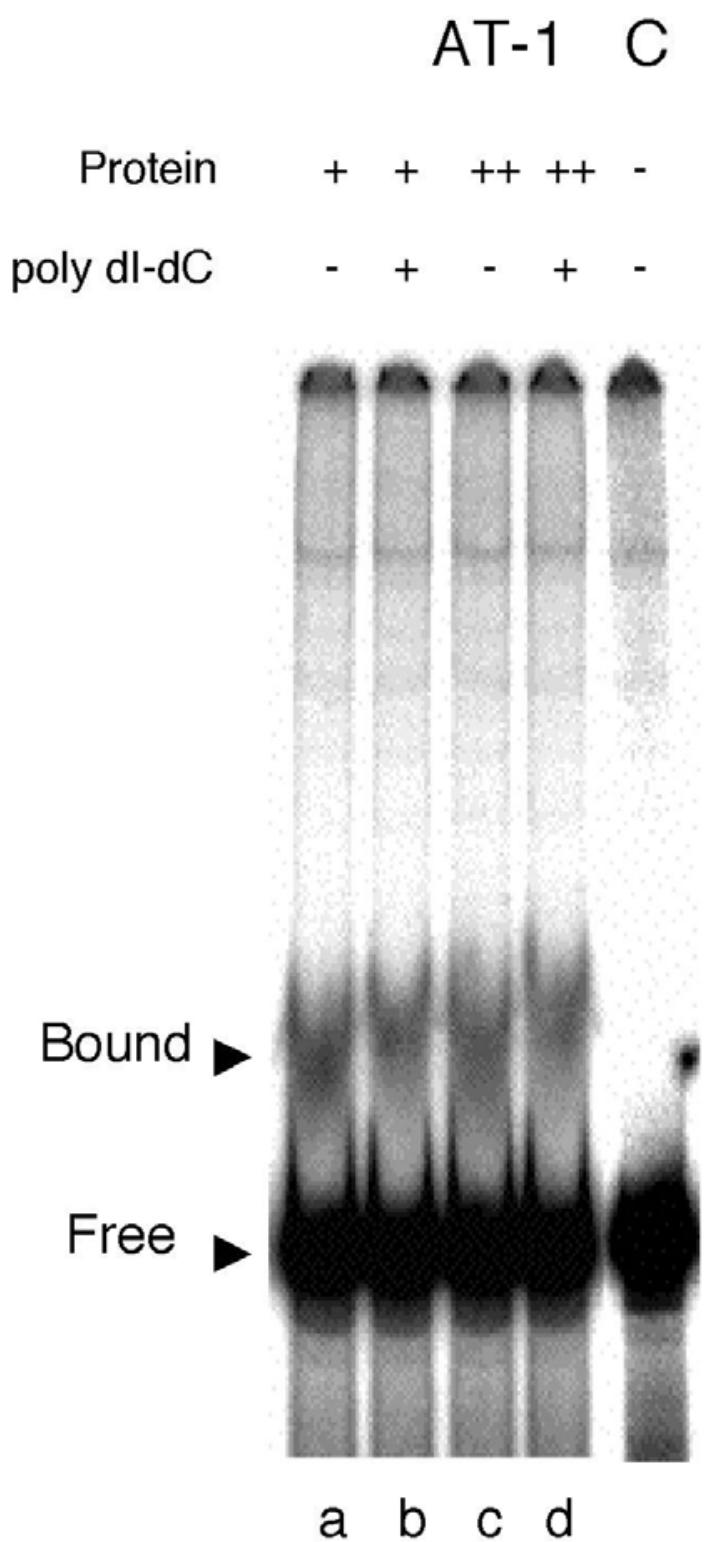

Figure 2. Gel retardation assay performed with cotyledon nuclear extracts and a restriction fragment containing the A/T-rich region starting at $-720 \mathrm{bp}$ in the upstream region of GS1a gene. Lanes a, b with protein nuclear extract $(4 \mu \mathrm{g})$ and 0 or $0.5 \mu \mathrm{g}$ of poly $\mathrm{dI}-\mathrm{dC}$ respectively. Lanes $\mathrm{c}$ and $\mathrm{d}$ the same except $5 \mu \mathrm{g}$ of protein nuclear extract was included. The $\mathrm{C}$ lane is a control without protein nuclear extract. All samples contained $2 \mu \mathrm{g}$ of salmon sperm DNA.

the DNA-protein complexes from unbound DNA. Figure 2 presents the results obtained in the gel retardation assay. The $173 \mathrm{bp}$ long AT-1 fragment (starting at $-720 \mathrm{bp}$ ) formed a complex that migrated more slowly than free DNA and that was not seen in the absence of nuclear proteins.

The AT-1 fragment represents an A/T rich region similar to rbcS, chs and Lhcb genes previously described [13, 20,
21]. We have identified the presence of cis elements in a light responsible promoter of a conifer GSI gene, but still experimental work is necessary to characterize further if the putative cis elements present in AT-1 region are functionally involved in regulation of the GSI $a$ gene expression by light.

Acknowledgements: We would like to thank Remedios Crespillo (Universidad de Málaga) for her excellent technical assistance and the research facilities of the Molecular Biology Laboratory, Research Services, Universidad de Málaga.

The nucleotide sequence data reported are available in the EMBL, GenBank and DDBJ Nucleotide Sequence Database under the accession number AJ225121.

\section{REFERENCES}

[1] Ávila C., García-Gutiérrez A., Crespillo R., Cánovas F.M., Effects of phosphinotricin treatment on glutamine synthetase isoforms in Scots pine seedlings, Plant Physiol. Biochem. 36 (1998) 857-863.

[2] Ávila C., Muñoz-Chápuli R., Plomion C., Frigerio J.M., Cánovas F.M., Two genes encoding distinct cytosolic glutamine synthetases are closely linked in the pine genome, FEBS Lett. 477 (2000) 237-243.

[3] Ávila C., Suárez M.-F., Gómez-Maldonado J., Cánovas F.M., Spatial and temporal expression of two cytosolic glutamine synthetase genes in Scots pine: functional implications on nitrogen metabolism during early stages of conifer development, Plant J. 25 (2001) 93-102.

[4] Barrett J.W., Beech R.N., Dancik B.P., Strobeck C., A genomic clone of a type I cab gene encoding a light harvesting chlorophyll $\mathrm{a} / \mathrm{b}$ binding protein of photosystem II identified from lodgepole pine, Genome 31 (1994) 166-172.

[5] Bechtold N., Ellis J., Pelletier G., In planta Agrobacterium mediated gene transfer by infiltration of adult Arabidopsis thaliana plants, CR Acad. Sci. Paris, Life Sciences 816 (1993) 1194-1199.

[6] Cánovas F.M., Cantón F.R., Gallardo F., García-Gutiérrez A., de Vicente A., Accumulation of glutamine synthetase during early development of maritime pine (Pinus pinaster) seedlings, Planta 185 (1991) 372-378.

[7] Cánovas F.M., Cantón F.R., García-Gutiérrez A., Crespillo R., Gallardo F., Molecular physiology of glutamine and glutamate biosynthesis in developing conifer seedlings, Plant Physiol. 103 (1998) 287-294.

[8] Cantón F.R., García-Gutiérrez A., Gallardo F., de Vicente A., Cánovas F.M., Molecular characterization of a cDNA clone encoding glutamine synthetase from a gymnosperm Pinus sylvestris, Plant Mol. Biol. 22 (1993) 819-828.

[9] Cantón F.R., Suárez M.-F., Josè-Estanyol M., Cánovas F.M., Expression analysis of a cytosolic glutamine synthetase gene in cotyledons of Scots pine seedlings: Developmental, light/dark regulation and spatial distribution of specific transcripts, Plant Mol. Biol. 40 (1999) 623-634.

[10] Forde B.G., Day H.M., Turton J.F., Shen W.J., Cullimore J.V., Oliver J.E., Two glutamine synthetase genes from Phaseolus vulgaris L. display contrasting developmental and spatial patterns of expression in transgenic Lotus corniculatus plants, Plant Cell 1 (1989) 391-401.

[11] Forde B.G., Freeman J., Oliver J.E., Pineda M., Nuclear factors Interact with conserved A/T-rich Elements Upstream of a Nodule-Enhanced Glutamine Synthetase gene from French Bean, Plant Cell 2 (1990) 925-939.

[12] García-Gutiérrez A., Dubois F., Cantón F.R., Gallardo F., Sangwan R.S., Cánovas F.M., Two different modes of early development and nitrogen assimilation in gymnosperm seedlings, Plant J. 13 (1998) 187-199.

[13] Hutchinson K.W., Harvie P.D., Singer P.V., Brunner A.F., Greenwood M.S., Nucleotide sequence of the small subunit of ribulose-1,5-biphosphate carboxylase from the conifer Larix laricinia, Plant Mol. Biol. 14 (1990) 281-284.

[14] Jefferson R.A., Assaying chimeric genes in plants: The GUS gene fusion system, Plant Mol. Biol. 5 (1987) 387-405. 
[15] Jefferson R.A., Kavanagh T.A., Bevan M.W., GUS fusions: $\beta$-glucuronidase as a sensitive and versatile gene fusion marker in higher plants, EMBO J. 6 (1987) 3901-3907.

[16] Kojima K., Yamamoto N., Sasaki S., Structure of the pine Structure of the pine (Pinus thunberghii) chlorophyll a/b-binding protein gene expressed in the absence of light, Plant Mol. Biol. 19 (1992) 405-410.

[17] Kojima K., Sasaki S., Yamamoto N., Light-independent and tissue-specific expression of a reporter gene mediated by the pine cab- 6 promoter in transgenic tobacco, Plant J. 6 (1994) 591-596.

[18] Loopstra C.A., Sederoff R.R., Xylem-specific gene expression in loblolly pine, Plant Mol. Biol. 27 (1995) 277-291.

[19] Rey M., Humara J.M., López M., González M.V., Rodríguez R., Tavazza R., Ancora G., Ordás R.J., Foreign gene expression in Pinus nigra, $P$. radiata and $P$. pinea following particle bombardment, in: Ahuja M.R., Boer- jan W., Neale D. (Eds.), Somatic Cell Genetics and Molecular Genetics of Trees, Kluwer Academic Publishers, Dordrecht, 1996, pp. 113-117.

[20] Lubberstedt T., Oelmüller R., Wanner G., Herrmann R.G., Interacting cis elements in the plastocyanin promoter from spinach, ensure regulated high-level expression, Mol. Gen. Genet. 242 (1994) 602-613.

[21] Park S.-C., Kwon H.-B., Shih M.C., Cis-acting elements essential for light regulation of the nuclear gene encoding the A subunit of chloroplast glyceraldehyde 3-phosphate dehydrogenase in Arabidopsis thaliana, Plant Physiol. 112 (1996) 1563-1571.

[22] Simpson C.G., Leader D.J., Brown J.W.S., Characteristics of plants pre-mRNA introns and transposable elements, in: Croy R.R.D. (Ed.), Plant Molecular Biology Labfax, BIOS Scientific Publishers, Oxford 1993, pp. 183-251.

[23] Simpson G.G., Filipowicz W., Splicing of precursors to mRNA in higher plants: mechanism, regulation and sub-nuclear organization of the spliceosomal machinery, Plant Mol. Biol. 32 (1996) 1-41.

To access this journal online: www.edpsciences.org 
